\title{
THE CREATION OF NEW SPORTS AND SPORTS VENUES
}

\author{
Mihai Constantin Răzvan BARBU, Andrei Aurel Anton TOHĂNEANU, Dragoş Laurențiu \\ DIACONESCU, George Bogdan BURCEA, Marius Cătălin POPESCU, Marian DRAGOMIR
}

\author{
University of Craiova, Faculty of Physical Education and Sport, Craiova \\ email:mihai.barbu@edu.ucv.ro
}

\section{https://doi.org/10.52846/jskm/37.2021.1.2}

\section{Abstract:}

The benefits of sport are so many, but we relate only to those of a physical nature. What we often forget to mention is that sport feeds our minds. It helps us develop the ability to think and stimulates our desire to be more competitive. It is a factor that favours evolution at the leadership level. Sport is a promoter of fair play, as part of a person's lifestyle.

It is a link between emotions and how they are interpreted by the brain. Emotional intelligence is stimulated when you do sports frequently. It helps to increase the level of stress resistance. It gives you the opportunity to discipline yourself and promotes the organizational spirit. Here, sport is not just a benefit for the body. It is also a form of improvement for you, on a human and social level. In the 21 st century, sports no longer meant classic sports activities. Extreme sports have emerged, those that take everything to another level. Sport has gone into the digital dimension and people can enjoy virtual sports.

In the paper "The creation of new sports and sports venues" we wanted to offer a brief presentation of how the first sports appeared, the main factors that contribute to the emergence of new sports and the creation of new sports venues, and a presentation of the newest and bizarre sports that have appeared in recent years, such as and the most impressive sports venues built.

Keywords: new sports, sports venues, technology.

\section{Introduction}

Sport is one of the most important aspects of life. Nowadays, physical activity plays a key role in the life of each of us. Whether we like it or not, it is important to exercise every day for a healthy and balanced life. Sport has many benefits on physical and mental health. Sport strengthens our immune system, strengthens our body, increases self-confidence, helps prolong life and makes us happier due to the serotonin secreted in the body (Nauright, J., 2004). In addition, playing sports helps with socialization and entertainment.

A first aspect that makes people practice sports is the need to exercise. The human body was designed to be active. Although nowadays the sedentary lifestyle is imposed by society, a few minutes of exercise a day are welcome. Another reason to practice sports, whether it is team or individual sports is the inner desire of each person to defeat the opponent. This instinct has always been part of people's lives and helped them survive over time. Whatever the reason we decide to do sports, it is good to know that our ancestors took care to implement a set of strict rules related to sports competitions.

The concept of sport appeared a long time ago. In the past, sport was considered a good way to train and maintain body shape (Bairner, A., 2001). In other words, at that time people were primarily interested in being fit, but also in being more disciplined. These reasons are still found today among sports enthusiasts. However, at that time the concept of sport was not as large as it is today. Nowadays games are varied and people can choose from several options when choosing mind games and more.

\section{Why and how sports came about}

Sport plays an essential role in the life of every person nowadays. In addition to the many benefits, it has on our physical and mental health, physical activity is often considered an excellent way to socialize or entertain (Stroe and Barbu, 2006). Sport comes from the need for movement, but also from the inner desire of each of us to defeat the opponent and to show what we are capable of when we put every cell of our body to work (Boyle, 2009). For some it is part of the daily routine, while others associate any form of movement with a high level of stress.

However, it seems that since ancient times people have invented rules according to which to be crowned after a sports competition. It is for this reason that it is essential to find out how some of 
the oldest sports appeared and how they developed over time.

When it comes to the advent of sports, many people wonder which were the most popular, when they appeared and what their origin was. Not many people wonder why they came about. The answer is relatively simple. As now, sports have always been a great way to have fun.

Prehistoric man did not have many methods of spending his free time, unlike modern man. In the past, people's main activities were providing food, finding shelter and making tools for hunting, cooking or fishing. So, in order to get rid of this "routine", people felt the need to invent various games to relax them.

It is true that modern technologies did not exist at the time, but people improvised using materials they had at hand (Cave and Miller, 2015). The pawns or dice of board games were made of stones, teeth or bones, while the balls were made of rags, materials they had at hand and animal skins.

There are currently many sports that can be practiced. However, in the past the options were limited. The most popular tests included running, long jump, javelin throwing, discuss throwing, obstacle course or chariot race. All these images are alive in people's minds due to the representations discovered by archaeologists.

As nowadays, board games have been a great source of entertainment. The competitive spirit of the people has made them want to defeat their opponent since ancient times. Each people had its own set of rules from which they did not deviate. The only major difference with this type of activity was that in the past people did not have as many options as now.

A first curiosity related to the first ancient competitions are the prizes. As there were not so many resources or medals made of precious materials at that time, the winners most often received a wreath of leaves. This symbol signified that nature itself crowns the one who has become the winner. Also, many athletes had only one goal, to get the Nike victory.

Gladiators are among the most famous athletes of the ancient world. They practiced several sports. These include: ball games, swimming or athletics. However, none of these sports have become as popular as gladiator fights.

Another curiosity about gladiatorial fights is that they could only be organized by emperors, magistrates and priests of the imperial cult.

The first Olympic Games took place in 776 BC, an event that began with a religious festival.
These sports competitions took place in a city called Olympia, where several ceremonies took place (Barbu, 2004).

Sport in its essence is health. Even though physical activities have developed considerably since their inception, the reasons why they are practiced have remained about the same (Cosma et al., 2017). In conclusion, it can be said that sport has ennobled man for a very long time. An important thing is not to forget where the sport started and not to lose the competitive spirit inherited from our ancestors (Mossberg and Hallberg,1999).

\section{Factors that determine the creation of new sports and sports venues}

Since ancient times, people have practiced various sports. Proof of this are the images depicting people moving and taking part in various sports competitions. In other words, they have since realized the role of physical movement in society, especially if we consider that it was considered a way of education. Nowadays, things have not changed much. Sport is still an integral part of people's lives. The human body needs movement to keep diseases away and to be able to function at full capacity (Barbu and Barbu, 2012).

The lives of people without sports are almost impossible. It is advisable to exercise constantly to prepare the body for a healthy life and an easy old age. Many people only know the benefits of the physical, but it is important to mention that physical activity stimulates the brain and can alleviate various mental problems (Chalip, et al., 2003). Here are some other beneficial factors that sport has on people's lives.

Because we live in the 21st century, sport no longer means classic sports activities. Various sports have emerged, taking everything to another level. Sport has gone into the digital dimension and people can enjoy virtual sports. This century is one in which, more than ever, sport has a new chance. Not just to become more beloved, but to become part of what people are. To gain the importance it deserves. To be not only a factor of relaxation, but also an active form of life support (Barbu, 2009).

One of the factors that led to the emergence of new sports is the technological evolution, its applicability in a vast number of fields has always been a benefit (Barbu et al., 2020). It is not surprising that the world of sports has gained a lot from technological discoveries. Applying certain improvements of this kind in sports has not only been a great advantage, but in some cases, it can 
be said that it has revolutionized this world of competition.

So, man has always sought to feel (live) something more special than the deeds of the day, which characterize everyday life. Due to the increasingly sedentary life that characterizes the modern world, man has come to feel a growing need to release the energy accumulated over the day. Traditional sports have begun to be overlooked, as strong (extreme) emotions have come to give man a new perspective on everyday life, which has too often become empty of content, boring and "tasteless."

Thus, in the last few decades, the need for "new" and sensational has become more and more widespread, man seeking in every way possible to test his limits, in the desire to feel better adrenaline. This quickly led to the emergence of new sports.

Traditional sports, although they are so many and diverse, are no longer matched with the digital needs and the desire to defy the limits, which characterize our world better and better, have begun to no longer please modern man. New sports conquer very quickly those who seek to be different from others, those who seek to live the sensational systematically.

The man, more and more dissatisfied with the traditional things, is in a continuous search for something new and sensational. Thus, in his free time he wants to do something "new", something "special" every time, something as different as the others. Thus, we see how the commercial messages encountered during the day urge people to have courage, to dare and not to be afraid of anything. For the most part, the ads push people to go beyond traditional life, as well as all its natural features, proclaiming messages such as: "Just do it!" (Without prejudice, without too many calculations, simply do what you want.)

Recent years have seen the constant introduction of technology into the world of sports - which has not only led to the emergence of new sports or sports venues, but has also led to increased fan appreciation of games, improved public profiles of athletes and information about their methods. training, even influencing the way competitions take place (Fried, 2005).

In recent years, technology and technological advances in the world of sports have seen predominant.

In sports, technology has improved the accuracy, enjoyment and experience of both athletes and spectators at sporting events around the world (Hall, 2006). Key advances in technology past, present and future have contributed to improving the sport for all. From fans, to coaches, to referees, and even to players, technology has evolved and so have our pastimes (Barbu and Barbu, 2011).

Technology is transforming our experience of modern sporting events and the venues that host them.

In the past, catering for spectators at a sporting event meant giving them a seat or a place to stand that had reasonable sightlines to the field of play. This is no longer sufficient.

Converged technologies now enable spectators to interact with an event long before they reach the venue (Klein, 2006). Shared information platforms deliver the same information to you whether you're at home or on the move.

\section{Findings:}

In the following lines we will present some of the strangest and newest sports, as well as the most impressive sports venues built, in order to offer fans a complete experience.

\section{The newest sports created \\ SPORT CLIMBING}

Sport climbing is the overcoming by the competitor of the natural or artificial obstacles of a steep terrain. It includes its three disciplines: speed, bouldering and difficulty.

In the speed test there will be a race between two climbers, both climbing a route set on a wall of 15 meters. In bouldering, climbers will climb a set number of routes on a four-meter wall in a specified period of time. In the difficulty test, the participants try to climb as much as possible on a wall longer than 15 meters, in a given period of time. Safety ropes are allowed in some disciplines, but this is the only equipment accepted and competitors must climb using only their hands and feet. This sport requires flexibility, strength, technique but also the ability to plan and make a strategy before the race.

\section{SURFING}

Surfing is a surface water sport. As for surfing, it is believed to have been part of ancient Polynesian culture and was first observed by Europeans. Some people practice surfing as a recreational activity while others dedicate their entire lives to the sport.

\section{WINDSURFING}

Also, on the same line is windsurfing, another water sport, practiced with the help of a windsurfing board, known as a surfboard, which is driven by a single sail. This extreme sport is a perfect combination of sailing and surfing. The wind of about 15-25 knots creates an ideal 
environment for windsurfing. It appeared in the 1960s, but did not reach its heyday until the 1980s, which led to its recognition as an Olympic sport in 1884.

\section{HANG GLIDING}

This is an aerial sport in which the pilot flies with the aircraft hanging in the harness. The pilots operate the aircraft by changing their body weight or by modern aircraft control systems. Given technological advances, today's pilots can fly long distances and perform acrobatics.

\section{CHESS BOXING}

Have you ever thought that chess and boxing can be found in the same ring? Well, this sport was invented. Chess boxing has been around for some time, more precisely since 1992 . As the name suggests, players who enter the ring must be proficient in both the sport of the mind and the physical confrontation.

In chess boxing, 11 rounds are played, some being boxing and others chess. The first championship took place in 2003, in Berlin, becoming more and more popular in Europe. Since 2011, chess boxing has a professional league and championships around the world.

\section{KARATE}

Karate is a martial art born in Japan in 1922 and the word itself paints a pretty clear picture: "kara" means "naked" in Japanese and "you" means "hand". So we have the sport empty handed. Being a contact sport, they can be used with the hands, elbows, palms, feet and knees.

Karate has two branches of it: kumite and kata. Kumite is the classic karate fights, known to everyone. Kata is a demonstration of previously prepared moves, in which the two competitors do not come into contact with each other.

\section{SKATEBOARDING}

Skateboarding as a professional sport comes with a series of competitions, both street style and bowl or vert style. Thus, vert skate involves schemes performed on half-pipe ramps, initially created to mimic empty pools. The street one involves tricks in an urban environment, with stairs, railings and other obstacles.

A youth subculture has been developed that emphasizes creativity and athletic individuality, being an alternative to team sports.

Today, skateboarding often exceeds the limits of a sport, simply becoming a lifestyle for those who practice it.

\section{CARRYING THE WIFE}

Already quite popular, carrying a wife is one of the strangest sports in the world. The name explains what the participants have to do.
Specifically, couples can enter these strange competitions, and gentlemen carry their wives or girlfriends along an obstacle course. The first to cross the finish line wins. Of course, until the end, the participants have to walk through water, mud and more. Wife's Carry has a world championship, which has been held annually in Sonkajarvi, Finland, since 1992. Oh, yes! And the prize is worth it! The winner receives a quantity of beer equal to his wife's weight.

\section{WRESTLING WITH TOES}

Has wrestling become too boring for you? Then you can challenge your friends to a wrestling game with your toes. Yes, you read that right! This sport was invented by four Englishmen, who were dissatisfied with the fact that Great Britain did not have enough world champions in the 70's. Thus, the four decided that their country can also enjoy the laurels of victory, especially if it is a sport that no one has heard of. This is how wrestling with the toes was born, but instead of remaining anonymous, as its creators initially wanted, it has become one of the strangest sports in the world, being practiced in more and more countries.

\section{QUIDDITCH}

If you haven't read the wonderful Harry Potter books yet, we'll quickly get you started on the Quidditch game. In the novel, this sport dedicated to wizards is played at height, the players flying on brooms. There are two teams entering the field. Because unfortunately we do not have flying brooms, in the US the rules have been rewritten so that even those without magical powers can enjoy sports. This strange competition also has a world championship, currently the title is held by Australia. Countries such as the United Kingdom, Canada, France, Turkey, Belgium, Mexico, Norway, Spain, Germany, Italy, Austria, Slovenia, Brazil, South Korea, Poland and beyond also boast professional Quidditch teams.

\section{UNDERWATER HOCKEY}

If you are a hockey fan, you may be even more excited about underwater hockey. This sport is becoming more and more popular and it is very difficult. Largely following the rules of a regular ice game, underwater hockey is played on the bottom of a swimming pool.

Players try to take the puck to the opponent's goal, and whenever necessary they come to the surface for air.

\section{The most impressive sports venues created}

A sports venue is a building, structure, or place in which a sporting competition is held. 
There are stadiums which every sports fan dream of visiting. Places where people would kill to watch one game. Places where you can see the history oozing from the walls.

These are the stadiums where at one time or another something great took place, the stadiums that stand out from the rest.

When we talk about architectural value, we must not limit ourselves only to buildings or statues, because each structure, regardless of its destination, contributes to shaping the visual identity of a locality. And any developed city knows that investments in sports facilities (stadiums, multipurpose halls, sports facilities) contribute to the development of tourism, increase community involvement and significantly support a healthy economy.

A show of light and color, incendiary, electrifying atmosphere, ardent fans or just coming to the theater, legendary footballers, crowd bath, unforgettable events, frantic encouragement, lightning moods, sudden transitions from agony and ecstasy, happiness to victories, disappointment and sadness at defeats, impressive investments, important tourist objectives. They are the great arenas, the most famous stadiums in the world.

So, every year, new sports arenas, stadiums and gyms with impressive capacities, innovative technologies and great architectural value are inaugurated all over the world.

Among the most impressive sports venues built are:

Allianz Arena. The first sports venue comes from Munich, the construction cost 340 million euros and has a capacity of 70,000 seats. It is nicknamed the "belt of life" and the "rubber boat". A stadium tour lasts 75 minutes.

Moterrey Stadium, Mexico. Estadio BBVA Bancomer has a capacity of 53,500 seats, was inaugurated in 2015 and cost 200 million dollars. Not only the arena is spectacular, but also the surrounding landscape, with lofty mountain peaks that fully contribute to the charm of the area.

HPCA Stadium in Dharamsala, India, is an arena built for cricket, an extremely popular sport in this country. With a capacity of 23,000 seats, HPCA Stadium is home to the Himachal Pradesh Cricket Association, and the official grandstand is in the shape of a temple, while the Himalayas can be seen from all sides.

Estadi Comunal D'Andorra La Vella, in Andorra, is a small stadium that does not compare to the great arenas of Europe in London, Paris, Munich or Madrid. Instead, the landscape is also a dream here. The stadium seems forgotten in a luxury resort, again surrounded by lofty mountains.

Stade Velodrome in Marseille, France, was built in 1937 and has been renovated three times since, the last time in 2015. It is the stadium where the famous Olimpique Marseille, former UEFA Champions League winner, has a capacity of 67,394 seats. places.

London's Wembley Stadium remains one of the most important arenas in Europe and one of the most beautiful. With a capacity of 90,000 seats, the new Wembley was inaugurated in 2007, and the works cost no less than 789 million pounds.

Santiago Bernabeu, the stadium of Messi's eternal rival, Real Madrid. Its capacity is 80,354 seats. It is said to be the stadium with the most modern locker rooms.

Considered one of the most beautiful stadiums in the world, Giuseppe Meazza, better known as the San Siro, is the place where AC Milan and Internationale Milano play their home matches. It has a capacity of 82,955 seats and is located in the western part of the Italian city of Milan. The lawn where Milan's fans live is colored in red and black, and that of Inter in blue.

The five-star arena of Cluj has a capacity of 30,201 seats, 8-lane athletics track and a modern drainage and heating system. Cluj Arena, the most performing stadium in Transylvania, a real architectural gem cost only 45 million euros.

The first elite stadium in Romania is located in Bucharest and is called the National Arena. With a capacity of 55,000 seats and an area of 108,000 square meters, the construction cost 234 million euros.

\section{Conclusions}

The emergence of new sports may be due either to the fact that people are tired of old sports, or they want them to fit better with their personality, or due to the evolution of technology that has allowed the development of many branches in sports. In terms of creating new sports venues, this is largely due to digitalization. Among the things it impresses with could be the amazing architecture, tradition, history, crowd environment or gaming experience. There are a lot of ways in which sports venues stand out. But especially because when a fan first enters a stadium with a list of cups, the feeling is unmistakable and unforgettable. It's magic.These sports venues are some of the most magical places in the world and everyone should experience them at least once. And any developed city knows that investments in 
sports facilities (stadiums, multipurpose halls, sports facilities) contribute to the development of tourism, increase community involvement and significantly support a healthy economy. Sport is one of the most important aspects of life. Nowadays, physical activity plays a key role in the life of each of us. Nowadays games are varied and people can choose from several options when choosing mind games and more.

Sport is still an integral part of people's lives. The human body needs movement to keep diseases away and to be able to function at full capacity.

\section{Acknowledgements}

Authors' contributions. Each author contributed equally to the study and writing of the article.

\section{References}

Bairner, A. (2001). Sport, Nationalism and Globalization: European and North American Perspectives. Albany, State University of New York Press.

Barbu, M. (2004). Istoria educaţiei fizice şi sportului. Craiova, Editura Universitaria.

Barbu, M. (2009). Managementul activităţii sportive din România. Craiova, Editura Universitaria.

Barbu, M.C.R., Barbu M.C. (2012). Training of personnel in leadership positions in sport organizations. Studia Universitatis BabesBolyai, Educatio Artis Gymnasticae, 57(3), 4151.

Barbu, M.C.R., Barbu, C.M. (2011). The management of a public funded sport club in times of crisis-a case study at CSM Craiova. Journal of Physical Education and Sport, 11(4), 455-460.

Barbu, M.C.R., Barbu, C.M., \& Diaconescu, D.L. (2020). Marketing developments in the sharing economy. In: R. Pamfilie, V. Dinu, L. Tăchiciu, D. Pleșea, C. Vasiliu eds. $6^{\text {th }} B A S I Q$ International Conference on New Trends in Sustainable Business and Consumption,
Messina, Italy, 4-6 June 2020. Bucharest: ASE, 97-104.

Boyle, R., Haynes, R. (2009). Power Play - Sport, the Media and Popular Culture, 2nd Edition. Edinburgh, Edinburgh University Press.

Cave, A., Miller, A. (2015). Technology in sport: the speed of science. The Telegraph, August, 25. Available on: http://www.telegraph.co.uk/sponsored/business /business-sport-series/11814716/technologyinsport.html.

Chalip, L., Green, B.C., \& Hill, B. (2003). Effects of sport event media on destination image and intention to visit. Journal of Sport Management, 17, 214-234.

Cosma, G., Nanu, M., Burcea, B., Barbu, D., \& Cosma, A. (2017). Pregătirea fizică în sportul de performanță. Craiova, Editura Universitaria.

Fried, G. (2005). Managing sport facilities. Champaign, IL, Human Kinetics.

Hall, S. (2006). Effective security management of university sport venues. The Sport Journal, 9(4).

Khan, E. (2019). Top 10 Unusual Sports You've Probably Never Heard Of. Available on: https://www.wonderslist.com/top-10-unusualsports/

Klein, A.M. (2006). Growing the Game: The Globalization of Major League Baseball. New Haven, CT, Yale University Press.

Mossberg, L.L., Hallberg, A. (1999). The presence of a mega-event: Effects on destination image and product-country images. Pacific Tourism Review, 3, 213-225.

Nauright, J. (2004). Global games: Culture, political economy, and sport in the globalized world of the twenty-first century. Third World Quarterly, 25(7), 1325-1336.

Stroe, C.A., Barbu, M. (2006). Impactul sportului asupra economiei. Craiova, Editura Universitaria. 